\title{
Lead and Cadmium Content in Grass Growing Near An Expressway
}

\author{
Kazimierz Jankowski ${ }^{1}$ Elżbieta Malinowska' ${ }^{1}$ Grażyna A. Ciepiela ${ }^{1}$ · Jolanta Jankowska ${ }^{1}$. \\ Beata Wiśniewska-Kadżajan ${ }^{1} \cdot$ Jacek Sosnowski ${ }^{1}$
}

Received: 22 January 2018 / Accepted: 17 September 2018 / Published online: 26 September 2018

(c) The Author(s) 2018

\begin{abstract}
The purpose of the study was to evaluate the effect of distance from a road on lead and cadmium content in grass species near an expressway and to assess bioaccumulation of these elements by morphological parts of the plants. The material for the research was the following grass species in their flowering stage: Dactylis glomerata, Arrenatherum elatius, and Alopecurus pratensis. Plant samples were collected along the international E30 road, the ring-road of Siedlce, in May 2015. A 9-km road section was examined with samples collected on both sides, covering a stretch of $700 \mathrm{~m}$, at the following distances from the edge of the road: 1, 5, 10, and $15 \mathrm{~m}$. Five samples of each plant species and at each distance from the road were collected. Lead and cadmium concentration was determined with the AAS method. The largest amounts of $\mathrm{Pb}$ were absorbed by $A$. pratensis L. (3.843 mg kg $\left.{ }^{-1} \mathrm{DM}\right)$, while the lowest by A. elatius $\mathrm{L}$. $\left(2.523 \mathrm{mg} \mathrm{kg}^{-1} \mathrm{DM}\right)$. Of the above plants, the highest amount of $\mathrm{Cd}\left(0.286 \mathrm{mg} \mathrm{kg}^{-1} \mathrm{DM}\right)$ was accumulated by $D$. glomerata $\mathrm{L}$. Underground parts of the grass species accumulated greater amounts of $\mathrm{Pb}$ and $\mathrm{Cd}$ than aboveground parts. It indicates that considerable amounts of heavy metals released by expressway vehicles contaminated the soil. The highest content of $\mathrm{Pb}$ and $\mathrm{Cd}$ was found in the grass growing at a distance of $5 \mathrm{~m}$ from the edge of the roadway, and this applies both to underground and aboveground parts.
\end{abstract}

Heavy metal contamination is a major concern, because it can lead, for example, to their bioaccumulation in the food chain, which affects human health (Peralta-Videa et al. 2009), to an inhibition of biodegradation of organic contaminants (Maslin and Maier 2000; Alloway 2013), to groundwater contamination (Mulligan et al. 2001), and to reduction of land and food quality (McLaughlin et al. 2000; Kabata-Pendias 2004; Gardea-Torresdey et al. 2005; Martin et al. 2017). According to Cicek et al. (2012), pollution from roadways and automobiles is now considered to be one of the largest sources of heavy metals. The contribution of road transport to the global emission of atmospheric pollutants is regularly increasing (Vachova et al. 2017; Cicek et al. 2012; Serbula et al. 2012).

The most important sources of heavy metals are brake lining wear, exhaust fumes, tire wear, crash barrier corrosion (Adachia and Tainosho 2004; McKenzie et al. 2009), or motor oil (Olajire and Ayodele 1997). Heavy metals, including lead and cadmium with the strongest impact on

Elżbieta Malinowska

malinowskae@uph.edu.pl

1 Faculty of Natural Science, Siedlce University of Natural Sciences and Humanities, Siedlce, Poland the environment, are among many chemical substances deposited near roads. However, their actual accumulation in plants is mainly connected with the bioaccumulation potential, which is species-specific (Jankowski et al. 2014).

Literature review in this field reveals that a variety of plants are used in monitoring accumulations of heavy metals, and most of them have produced successful results (Tomasevic et al. 2004; Chakrabortty and Paratkar 2006; Vachova et al. 2017). According to Cicek et al. (2012), more than 400 plant species, known as hyperaccumulators, from all over the world can accumulate high concentrations of metals at contaminated sites. The diverse ability of plants to accumulate heavy metals in aboveground parts is due to different morphology of plants (Deska et al. 2011; Jankowski et al. 2014). The structures on leaf surfaces, grooves, bristles, or specific chemicals, such as wax, play a major role in this process (Naszradi et al. 2004). They accumulate dust on the surface of plants in a variety of ways. There also are differences in accumulation of heavy metals in different parts of plants (Stafilov and Jordanovska 1997).

Some authors (Jankowski et al. 2014; Malinowska et al. 2015; Wiśniewska-Kadżajan et al. 2015) point out that of all plants grasses are typical groundcovers in areas adjacent to a roadway. Roadside sward is composed of grasses, which 
are usually planted there, but also of dicotyledonous herbs and weeds. The fact that grass can grow very quickly, even in small areas, and that it is an all-season plant is a reason why it was used in some studies in a very successful way to monitor pollution (Olajire and Ayodele 1997; Garcia and Milan 1998; Lai and Chen 2004; Filipek-Mazur et al. 2007; Cicek et al. 2012). Emission of heavy metals (lead and cadmium) coming from roads can cause diverse pollution of grass species and their morphological parts (De Nicola et al. 2003; Naszradi et al. 2004; Jankowski et al. 2015).

Heavy metals released by traffic pose the greatest threat to areas directly adjacent to roads. Road dust is a mixture of pollutants floating through the air, but it is also washed off road surfaces by rainwater or splashed by the wheels of moving cars onto the roadside (Werkenthin et al. 2014). The dust contains significant amounts of polycyclic aromatic hydrocarbons $(2.7 \mathrm{Mg}$ per year, which is $1-1.9 \%$ of total emission). In the EU countries, the annual air emission of lead $(\mathrm{Pb})$ is estimated at $2.4 \mathrm{Gg}$ and cadmium $(\mathrm{Cd})$ at $105 \mathrm{Mg}$. Poland's share in this emission is very significant, with $23 \%$ for $\mathrm{Pb}$ and $41 \%$ for $\mathrm{Cd}$ (European Environment Agency 2011). Road transport in the EU is responsible for $6 \%$ of the total emissions of $\mathrm{Pb}$ into the air (Pulles et al. 2012). The problem of environmental pollution associated with road transport continues to be complex, and it has not been studied exhaustively yet.

The purpose of the study was to evaluate the effect of distance from a fast road on the content of lead and cadmium in grass species and to assess bioaccumulation of these elements by morphological parts of the grasses.

\section{Materials and Methods}

The plant material for the research was morphological parts of the following grass species in their flowering stage: Dactylis glomerata, Arrenatherum elatius, and Alopecurus pratensis. Samples of plants were collected along the international E30 road, the ring-road of Siedlce (Figs. 1, 2) in May 2015. A 9-km road section was examined with samples collected on both sides covering a stretch of $700 \mathrm{~m}$ at the following distances from the edge of the road: $1,5,10$, and $15 \mathrm{~m}$. The total number of samples was 96 .

The E30 road is a part of the international traffic route from Cork (Ireland) to Omsk (Russia). In Poland, it passes through five provinces, but the range of the research covered only a section of the road in the Masovian province. The road section is located in the central-eastern part of Poland, approximately $80 \mathrm{~km}$ east of Warsaw. In 2015, the General Directorate for National Roads and Motorways (GDNR \& $\mathrm{M})$ counted the number of vehicles (SDR) on Polish roads, including the tested section (Table 1). The average of three counts of the daily number of motor vehicles (SDR) on international roads in 2015 was 20,067 vehicles/day, whereas on remaining national roads it was 7614 vehicles/day (General Directorate 2015). On the analysed section, the ring-road of Siedlce, the average daily movement of motor vehicles was higher than the average on national roads of Poland, and it was 11,465 vehicles/day (General Directorate 2015).

The average concentration of organic carbon in the soil sampled 1, 5, 10, and $15 \mathrm{~m}$ from the road was $9.05 \mathrm{~g} \mathrm{~kg}^{-1}$, while total nitrogen concentration was $0.57 \mathrm{~g} \mathrm{~kg}^{-1}$, and $\mathrm{pH}_{\mathrm{KCl}}$ was 4.10. The abovementioned samples were divided

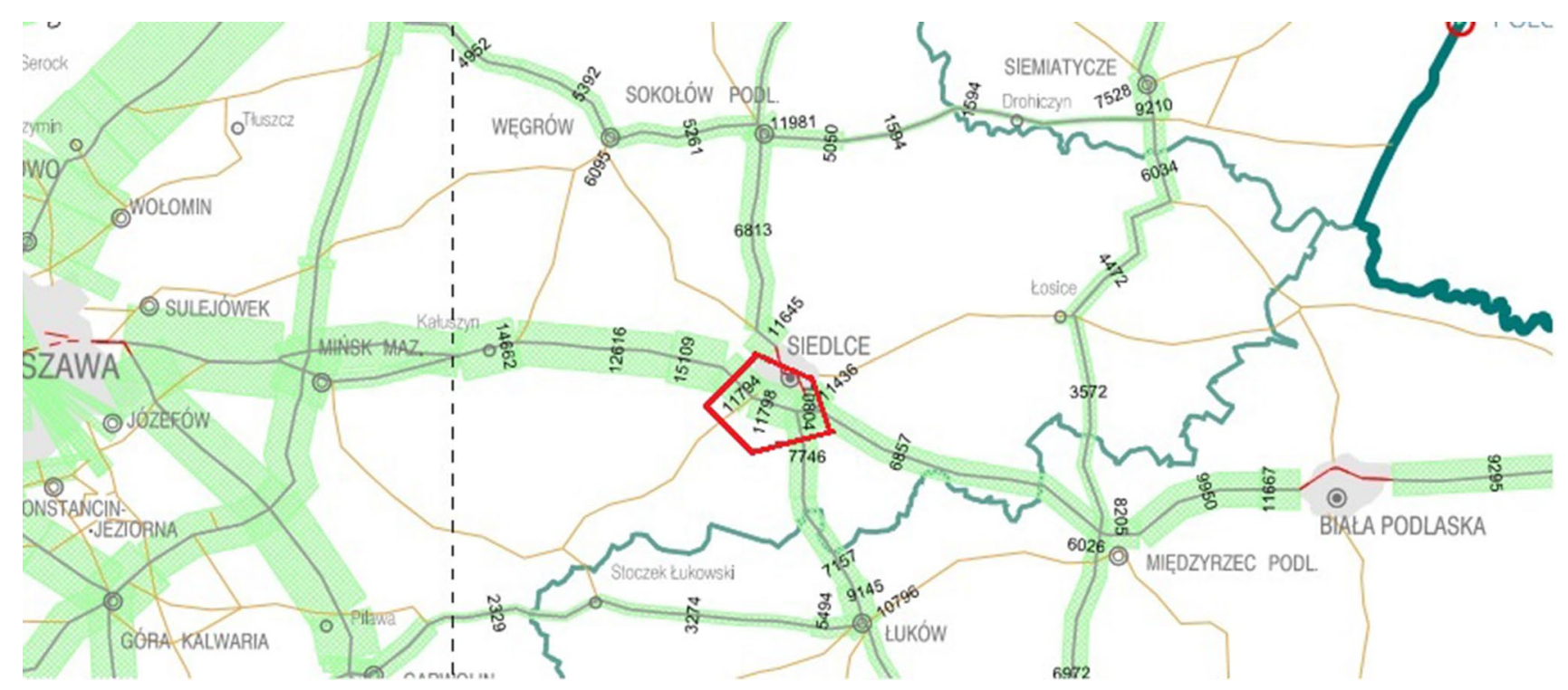

Fig. 1 Schematic representation of the studied sites of the E30 road (General Directorate 2015) 


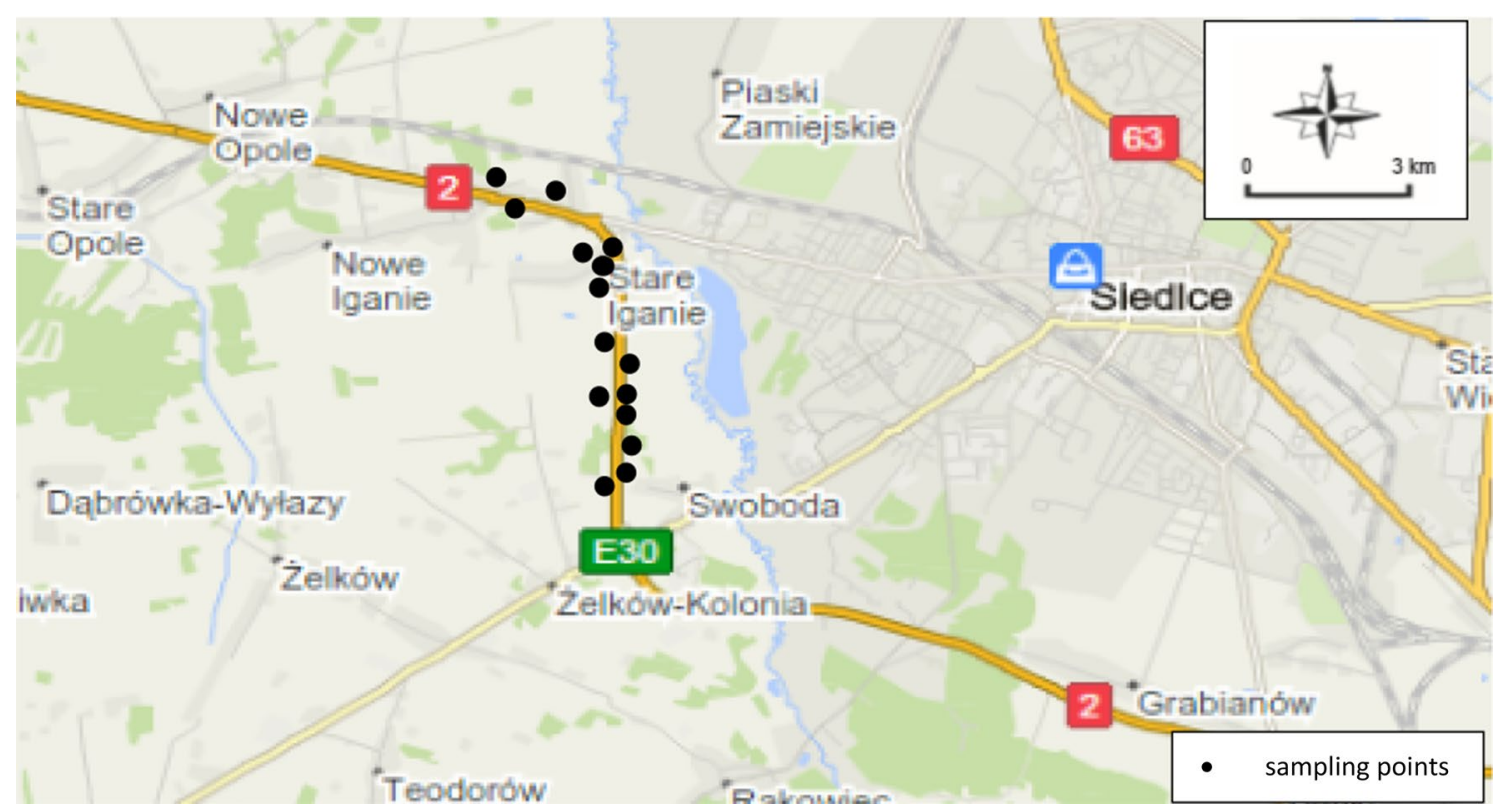

Fig. 2 Plant and soil sampling sites in the vicinity of the E30 expressway (openstreetmap.org/\#map=12/52.1036/22.1357)

Table 1 The average daily traffic of motor vehicles within the ring road of Siedlce (General Directorate 2015)

\begin{tabular}{|c|c|c|c|c|c|c|c|c|c|}
\hline \multirow{2}{*}{$\begin{array}{l}\text { Measur- } \\
\text { ing point } \\
\text { number }\end{array}$} & \multirow{2}{*}{$\begin{array}{l}\text { Distance } \\
\text { between meas- } \\
\text { uring points } \\
(\mathrm{km})\end{array}$} & \multirow{2}{*}{$\begin{array}{l}\text { Measuring } \\
\text { point name }\end{array}$} & \multirow{2}{*}{$\begin{array}{l}\text { The number } \\
\text { of vehicles per } \\
24 \mathrm{~h}\end{array}$} & \multirow[t]{2}{*}{ Motorcycles } & \multirow[t]{2}{*}{ Passenger cars } & \multirow[t]{2}{*}{ Vans } & \multicolumn{2}{|l|}{ Lorries } & \multirow[t]{2}{*}{ Coaches } \\
\hline & & & & & & & $\begin{array}{l}\text { Without trail- } \\
\text { ers }\end{array}$ & With trailers & \\
\hline 11,517 & 5.59 & $\begin{array}{l}\text { Siedlce/Ring } \\
\text { road } \\
1\end{array}$ & 11,794 & 63 & 8420 & 936 & 534 & 1793 & 47 \\
\hline 11,518 & 5.04 & $\begin{array}{l}\text { Siedlce/Ring } \\
\text { road } \\
2\end{array}$ & 11,798 & 36 & 7718 & 1240 & 628 & 2139 & 36 \\
\hline \multirow[t]{2}{*}{11,504} & 2.55 & $\begin{array}{l}\text { Siedlce/Ring } \\
\text { road } \\
3\end{array}$ & 10,804 & 34 & 7264 & 1017 & 540 & 1912 & 36 \\
\hline & Means & & 11,465 & 44 & 7800 & 1064 & 567 & 1948 & 40 \\
\hline
\end{tabular}

according to two morphological parts: aboveground and underground. Then, five samples of each plant species and from each distance from the road were selected. Next, plant material was dried in an oven (SUSLAB-PLE-406, SLW $1000 \mathrm{STD}$ ) at $105{ }^{\circ} \mathrm{C}$ for $48 \mathrm{~h}$. It was ground to $0.25 \mathrm{~mm}$ particle size with $1 \mathrm{~g}$ samples weighed out and poured into stoneware crucibles, and then organic matter was ashed at $450{ }^{\circ} \mathrm{C}$ in a muffle furnace (L3/11) for $18 \mathrm{~h}$, diluted in $10 \%$ $\mathrm{HNO}_{3}$, and transferred to a $100-\mathrm{ml}$ volumetric flask.

Lead and cadmium concentration was determined with the AAS method, by means of the Varian Spectra AA20 spectrophotometer (VARIAN, Australia), using the standards of the Merck company. The parameters of the spectrophotometer are: VARIAN, Australia; range of $190 \mathrm{~nm}$ to $900 \mathrm{~nm}$, equipped with a graphite cuvette type GTA-96.
An internal quality control system was used for validation of analytical methods. It was assumed that the average recovery of an internal standard should be in the range of $85 \%$ to $115 \%$ of the true value. For the needs of the research, two standards of quality control were prepared. One standard was added to a known amount of analyte. A recovery was calculated after the analysis of the sample with and without the analyte. The average recovery was dependent on the analyte content in the sample. The analysis was performed in each series of samples, and the obtained recovery was included in the assumed range.

To assess the impact of road traffic on the environment, the pollution index of heavy metals in the soil $\left(P_{i}\right)$ was determined (European Environment Agency 2011). It was calculated according to the formula: $P_{i}=\frac{C_{P}}{C_{u}}$ 
$\left[C_{p}\right.$ - the concentration of a metal in a polluted sample; $C_{u}$ - the concentration of a metal in a sample representing an unpolluted area with similar characteristics, for $\mathrm{Cd}$ it is $0.13 \mathrm{mg} \mathrm{kg}^{-1}$, and for $\mathrm{Pb}$ it is $7.10 \mathrm{mg} \mathrm{kg}^{-1}$ (Czarnowska 1996)].

$P_{i}$ values are classified in the three-range scale:

$P_{i} \leq 1$ low level pollution,

$1 \leq P_{i} \leq 3$ medium-level pollution,

$P_{i}>3$ high level pollution.

Simple correlation coefficient between the overall content of lead and cadmium in the soil and the content of these elements in above-ground and underground parts of selected grass species was also determined.

\section{Statistical Analysis}

The obtained data were processed statistically with the Statistica software, Version 10.0 StatSoft. The effects of the tested factors on lead and cadmium pollution was examined with two-factor analysis of variance. For the purpose of detailed comparison of means, Tukey's test was carried out at $p \leq 0.05$.

\section{Results}

The average content of $\mathrm{Pb}$ and $\mathrm{Cd}$ in the soil sampled at all distances from the expressway was 10.37 and $0.221 \mathrm{mg} \mathrm{kg}^{-1}$, respectively (Table 2). In the present study, the highest amounts of $\mathrm{Pb}\left(13.52 \mathrm{mg} \mathrm{kg}^{-1}\right)$ and $\mathrm{Cd}\left(0.333 \mathrm{mg} \mathrm{kg}^{-1}\right)$ were found in the soil at a sampling distance of $5 \mathrm{~m}$ from the roadway, but such concentration was not toxic to plants.

The content of both $\mathrm{Pb}$ and $\mathrm{Cd}$ in the aboveground parts of plants (Table 3) significantly varied and was dependent on both the distance from the roadway and grass

Table 2 Average concentration of $\mathrm{Pb}$ and $\mathrm{Cd}$ in the soil at all sampling distances from the expressway

\begin{tabular}{lll}
\hline Distance from the roadway $(\mathrm{m})$ & \multicolumn{2}{l}{$\begin{array}{l}\text { Average concentration in the soil } \\
\left(\mathrm{mg} \mathrm{kg}^{-1}\right)\end{array}$} \\
\cline { 2 - 3 } & $\mathrm{Pb}$ & $\mathrm{Cd}$ \\
\hline 1 & $7.28 \mathrm{D}$ & $0.189 \mathrm{C}$ \\
5 & $13.52 \mathrm{~A}$ & $0.333 \mathrm{~A}$ \\
10 & $10.65 \mathrm{~B}$ & $0.210 \mathrm{~B}$ \\
15 & $10.04 \mathrm{C}$ & $0.152 \mathrm{D}$ \\
Means & 10.37 & 0.221 \\
\hline
\end{tabular}

Within a column, different uppercase letters indicate a significant difference
Table 3 Concentration of $\mathrm{Cd}$ and $\mathrm{Pb}$ in the aboveground parts of selected grass species

\begin{tabular}{|c|c|c|c|}
\hline \multirow{2}{*}{$\begin{array}{l}\text { Distance from the } \\
\text { road }(m)\end{array}$} & \multirow[t]{2}{*}{ Grass species } & \multicolumn{2}{|c|}{ Concentration $\left(\mathrm{mg} \mathrm{kg}^{-1}\right)$} \\
\hline & & $\mathrm{Pb}$ & $\mathrm{Cd}$ \\
\hline \multirow[t]{3}{*}{1} & D. glomerata & 2.945 & 0.237 \\
\hline & A. elatius & 2.050 & 0.156 \\
\hline & A. pratensis & 2.859 & 0.095 \\
\hline \multirow[t]{3}{*}{5} & D. glomerata & 4.730 & 0.537 \\
\hline & A. elatius & 3.895 & 0.204 \\
\hline & A. pratensis & 3.489 & 0.187 \\
\hline \multirow[t]{3}{*}{10} & D. glomerata & 2.974 & 0.227 \\
\hline & A. elatius & 3.097 & 0.329 \\
\hline & A. pratensis & 4.517 & 0.144 \\
\hline \multirow[t]{3}{*}{15} & D. glomerata & 2.335 & 0.141 \\
\hline & A. elatius & 1.049 & 0.069 \\
\hline & A. pratensis & 4.506 & 0.139 \\
\hline \multicolumn{4}{|c|}{ Means for each distance } \\
\hline \multicolumn{2}{|l|}{1} & $2.618 \mathrm{C}$ & $0.163 \mathrm{C}$ \\
\hline \multicolumn{2}{|l|}{5} & $4.038 \mathrm{~A}$ & $0.309 \mathrm{~A}$ \\
\hline \multicolumn{2}{|l|}{10} & $3.529 \mathrm{~B}$ & $0.233 \mathrm{~B}$ \\
\hline \multicolumn{2}{|l|}{15} & $2.630 \mathrm{C}$ & $0.116 \mathrm{D}$ \\
\hline \multicolumn{4}{|c|}{ Means for each species } \\
\hline \multicolumn{2}{|c|}{ D. glomerata } & $3.246 \mathrm{~B}$ & $0.286 \mathrm{~A}$ \\
\hline \multicolumn{2}{|l|}{ A. elatius } & $2.523 \mathrm{C}$ & $0.190 \mathrm{~B}$ \\
\hline \multicolumn{2}{|l|}{ A. pratensis } & $3.843 \mathrm{~A}$ & $0.141 \mathrm{C}$ \\
\hline
\end{tabular}

Within a column, different uppercase letters indicate a significant difference

species. $\mathrm{Pb}$ concentration ranged from $1.049 \mathrm{mg} \mathrm{kg}^{-1} \mathrm{DM}$ in Arrhenatherum elatius collected at a distance of $15 \mathrm{~m}$ from the roadway to $4.730 \mathrm{mg} \mathrm{kg}^{-1} \mathrm{DM}$ in $D$. glomerata collected $5 \mathrm{~m}$ from the roadway. Of all the species, the greatest amount of $\mathrm{Pb}\left(3.843 \mathrm{mg} \mathrm{kg}^{-1} \mathrm{DM}\right)$ was absorbed by $A$. pratensis and the smallest $\left(3.246 \mathrm{mg} \mathrm{kg}^{-1} \mathrm{DM}\right)$ by $D$. glomerata. Differences in $\mathrm{Pb}$ content between grass species were statistically significant.

Of all samples collected at different distances from the road the smallest amount of $\mathrm{Pb}$, which was $2.618 \mathrm{mg} \mathrm{kg}^{-1} \mathrm{DM}$, was found in plants growing $1 \mathrm{~m}$ from the road, and the greatest amount of $4.038 \mathrm{mg} \mathrm{kg}^{-1} \mathrm{DM}$ was found at the next sampling point, $5 \mathrm{~m}$ from the road. Further away from the expressway $\mathrm{Pb}$ content in plants underwent systematic reduction. Differences between $\mathrm{Pb}$ content in aboveground parts sampled at different distances were statistically significant. Of all grass species and all distances from the expressway, it was found that the aboveground parts of D. glomerata and A. elatius accumulated most $\mathrm{Pb}$ when growing $5 \mathrm{~m}$ from the roadway, and the quantity of this chemical element decreased as their distance from the road increased. In turn, in A. pratensis $\mathrm{Pb}$ content increased when the distance from the road increased, reaching its highest 
concentration of $4.517 \mathrm{mg} \mathrm{kg}^{-1} \mathrm{DM}$ at the third distance, namely $10 \mathrm{~m}$ from the road.

In the present study, $\mathrm{Cd}$ content in aboveground parts of grass (Table 3) was much lower than in the case of $\mathrm{Pb}$. The amount of $\mathrm{Cd}$ significantly varied and was dependent on both the grass species and distance from the road. The concentration of this metal ranged from $0.069 \mathrm{mg} \mathrm{kg}^{-1} \mathrm{DM}$ in A. elatius sampled at a distance of $15 \mathrm{~m}$ from the road to $0.537 \mathrm{mg} \mathrm{kg}^{-1} \mathrm{DM}$ in D. glomerata collected $5 \mathrm{~m}$ from the road.

Comparing $\mathrm{Cd}$ concentration in all species, it was found that its greatest quantities of $0.286 \mathrm{mg} \mathrm{kg}^{-1} \mathrm{DM}$ were accumulated by $D$. glomerata, and the smallest, namely $0.141 \mathrm{mg} \mathrm{kg}^{-1} \mathrm{DM}$, by A. pratensis. Differences between Cd content in the aboveground parts were statistically significant. As in the case of $\mathrm{Pb}$, the largest quantities of $\mathrm{Cd}$ were accumulated by plants growing at a distance of $5 \mathrm{~m}$ from the $\operatorname{road}\left(0.309 \mathrm{mg} \mathrm{kg}^{-1} \mathrm{DM}\right)$, whereas at further distances $(10$ and $15 \mathrm{~m}$ ) the quantities systematically decreased.

As regards the interaction between grass species and sampling distances from the road, it was found that D. glomerata and $A$. pratensis accumulated the highest amounts of $\mathrm{Cd}$ when they grew $5 \mathrm{~m}$ from the road (0.537 and $0.187 \mathrm{mg} \mathrm{kg}^{-1} \mathrm{DM}$, respectively), whereas A. elatius had the highest $\mathrm{Cd}$ concentration at a further distance, $10 \mathrm{~m}$ from the road $\left(0.329 \mathrm{mg} \mathrm{kg}^{-1} \mathrm{DM}\right)$.

To assess plant quality to be used as forage for animals, determination of the content of heavy metals was made in accordance with the Regulation of the Minister of Agriculture and Rural Development of 23 January 2007 on the permissible content of undesirable substances in fodder (Regulations of the Minister for Agriculture and Rural Development 2007).

By comparing $\mathrm{Pb}$ and $\mathrm{Cd}$ content in the underground and aboveground parts of grass species, it was found that the amount of these chemical elements was almost twice higher in the former than in the latter. However, the content of $\mathrm{Pb}$ and $\mathrm{Cd}$ in the underground parts was significantly differentiated, depending on the grass species and distance from the road (Table 4). The species had similar abilities to accumulate $\mathrm{Cd}$ and $\mathrm{Pb}$ both in the roots and in the aboveground parts. On average, the highest content of $\mathrm{Pb}$ was in the roots of A. elatius $\left(6.233 \mathrm{mg} \mathrm{kg}^{-1}\right)$, and the highest content of $\mathrm{Cd}$ was in the underground parts of $D$. glomerata $\left(0.538 \mathrm{mg} \mathrm{kg}^{-1}\right)$. The highest content of both heavy metals in underground parts was found in grass collected at a distance of $5 \mathrm{~m}$ from the road.

The ratios of $\mathrm{Pb}$ and of $\mathrm{Cd}$ accumulation in aboveground parts to their accumulation in roots (MS/MR) are presented in Figs. 3 and 4. For all grass species, there were no significant differences between the average values of the $\mathrm{Pb}$ ratio.

However, there were significant differences in the ratio of $\mathrm{Pb}$ content between plant samples collected at different
Table 4 Concentration of $\mathrm{Cd}$ and $\mathrm{Pb}$ in the underground parts of selected grass species

\begin{tabular}{|c|c|c|c|}
\hline \multirow{2}{*}{$\begin{array}{l}\text { Distance from the } \\
\text { road }(m)\end{array}$} & \multirow[t]{2}{*}{ Grass species } & \multicolumn{2}{|c|}{ Concentration $\mathrm{mg} \mathrm{kg}^{-1}$} \\
\hline & & $\mathrm{Pb}$ & $\mathrm{Cd}$ \\
\hline \multirow[t]{3}{*}{1} & D. glomerata & 4.975 & 0.489 \\
\hline & A. elatius & 3.541 & 0.379 \\
\hline & A. pratensis & 5.249 & 0.426 \\
\hline \multirow[t]{3}{*}{5} & D. glomerata & 6.760 & 0.789 \\
\hline & A. elatius & 6.125 & 0.427 \\
\hline & A. pratensis & 5.879 & 0.516 \\
\hline \multirow[t]{3}{*}{10} & D. glomerata & 5.004 & 0.479 \\
\hline & A. elatius & 5.327 & 0.552 \\
\hline & A. pratensis & 6.907 & 0.473 \\
\hline \multirow[t]{3}{*}{15} & D. glomerata & 4.365 & 0.393 \\
\hline & A. elatius & 3.279 & 0.292 \\
\hline & A. pratensis & 6.896 & 0.468 \\
\hline \multicolumn{4}{|c|}{ Means for each distance } \\
\hline \multicolumn{2}{|l|}{1} & $4.588 \mathrm{D}$ & $0.434 \mathrm{C}$ \\
\hline \multicolumn{2}{|l|}{5} & $6.255 \mathrm{~A}$ & $0.577 \mathrm{~A}$ \\
\hline \multicolumn{2}{|l|}{10} & $5.746 \mathrm{~B}$ & $0.501 \mathrm{~B}$ \\
\hline \multicolumn{2}{|l|}{15} & $4.847 \mathrm{C}$ & $0.384 \mathrm{D}$ \\
\hline \multicolumn{4}{|c|}{ Means for each species } \\
\hline \multicolumn{2}{|c|}{ D. glomerata } & $5.276 \mathrm{~B}$ & $0.538 \mathrm{~A}$ \\
\hline \multicolumn{2}{|l|}{ A. elatius } & $4.568 \mathrm{C}$ & $0.413 \mathrm{C}$ \\
\hline \multicolumn{2}{|l|}{ A. pratensis } & $6.233 \mathrm{~A}$ & $0.471 \mathrm{~B}$ \\
\hline
\end{tabular}

Within a column, different uppercase letters indicate a significant difference

distances. The ratio value for $\mathrm{Cd}$ showed different responses of each grass species to the release of heavy metals by traffic. The lowest value of this indicator was reported in $A$. pratensis and the highest in D. glomerata. In the case of $\mathrm{Cd}$, there was a considerable variation of those values depending on the distance from the road but also on overall $\mathrm{Cd}$ content in the plant. In the case of $\mathrm{Pb}$ ratio, the values were higher than in the case of $\mathrm{Cd}$.

Comparing grass species containing the highest amounts of $\mathrm{Pb}$ and $\mathrm{Cd}$ (Table 5), it was found that the greatest concentration of $\mathrm{Pb}$ were accumulated by $D$. glomerata growing 1 and $5 \mathrm{~m}$ from the road and by $A$. pratensis growing 10 and $15 \mathrm{~m}$ from the road. However, Cd was accumulated by $D$. glomerata in high quantities at all distances, except $10 \mathrm{~m}$ from the road where A. elatius had the highest concentration of this chemical element.

The lowest content of both $\mathrm{Pb}$ and $\mathrm{Cd}$ varied and was dependent on both the type of grass and the distance from the road. There was no clear tendency for the same species to have the lowest $\mathrm{Pb}$ content at a few distances from the road. In turn, the smallest amounts of $\mathrm{Cd}$ were found primarily in A. pratensis growing 1 to $10 \mathrm{~m}$ from the road, whereas at a distance of $15 \mathrm{~m}$, its smallest content was found in A. elatius. 
Fig. 3 The ratio shoot/root $\left(M_{S} / M_{R}\right)$ in $\mathrm{Pb}$ content

Fig. 4 The ratio shoot/root $\left(M_{S} / M_{R}\right)$ in Cd content
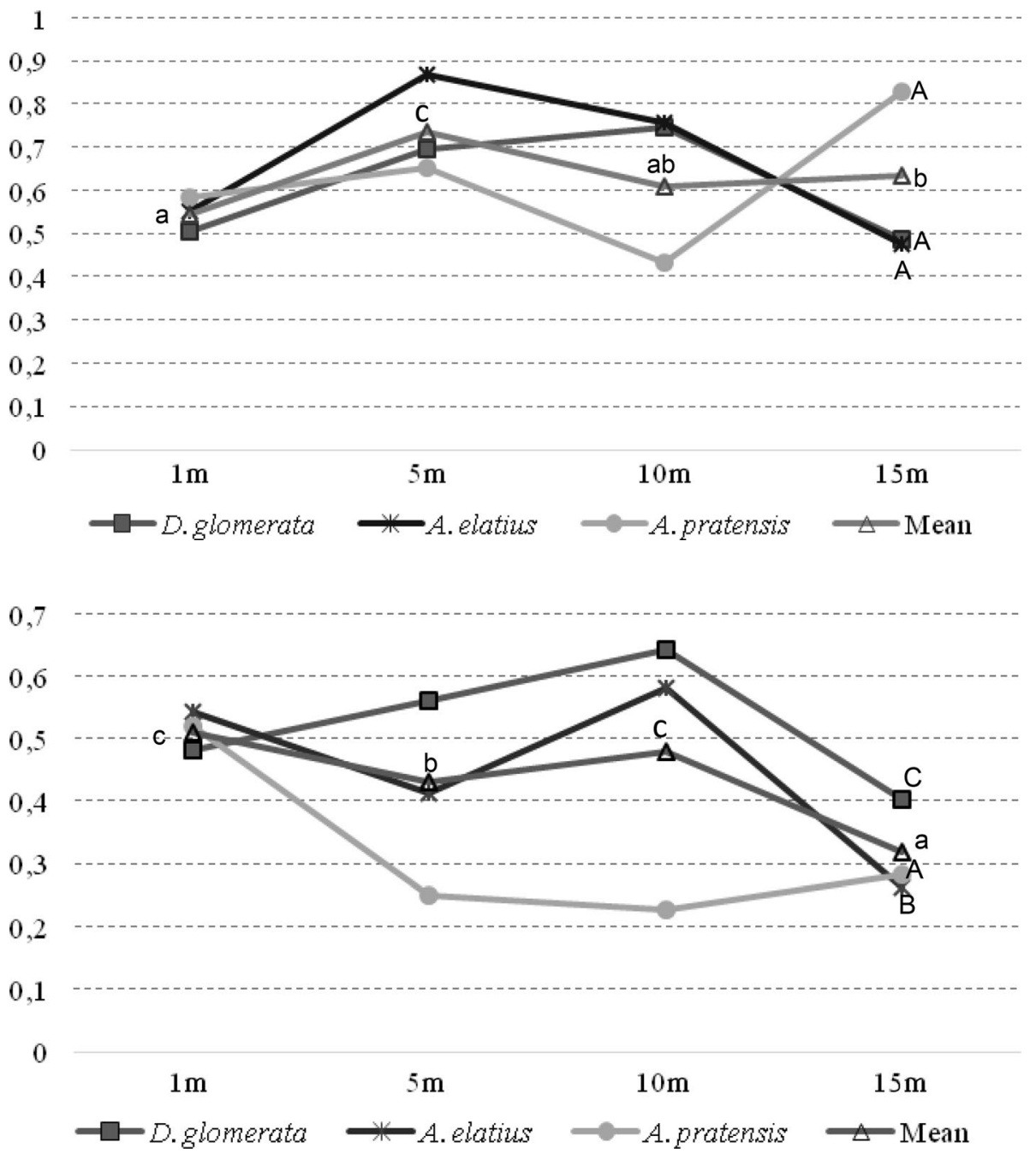

Table 5 Grass species with the highest and lowest accumulation of $\mathrm{Pb}$ and $\mathrm{Cd}$

\begin{tabular}{|c|c|c|c|c|}
\hline \multirow{2}{*}{$\begin{array}{l}\text { Distance from } \\
\text { the road }(\mathrm{m})\end{array}$} & \multicolumn{2}{|l|}{ Maximum } & \multicolumn{2}{|l|}{ Minimum } \\
\hline & $\mathrm{Pb}$ & $\mathrm{Cd}$ & $\mathrm{Pb}$ & $\mathrm{Cd}$ \\
\hline 1 & Dactylis glomerata & Dactylis glomerata & $\begin{array}{l}\text { Arrhenatherum } \\
\text { elatius }\end{array}$ & $\begin{array}{l}\text { Alopecurus } \\
\text { pratensis }\end{array}$ \\
\hline 5 & Dactylis glomerata & Dactylis glomerata & $\begin{array}{l}\text { Alopecurus } \\
\text { pratensis }\end{array}$ & $\begin{array}{l}\text { Alopecurus } \\
\text { pratensis }\end{array}$ \\
\hline 10 & $\begin{array}{l}\text { Alopecurus } \\
\text { pratensis }\end{array}$ & $\begin{array}{l}\text { Arrhenatherum } \\
\text { elatius }\end{array}$ & Dactylis glomerata & $\begin{array}{l}\text { Alopecurus } \\
\text { pratensis }\end{array}$ \\
\hline 15 & $\begin{array}{l}\text { Alopecurus } \\
\text { pratensis }\end{array}$ & Dactylis glomerata & $\begin{array}{l}\text { Arrhenatherum } \\
\text { elatius }\end{array}$ & $\begin{array}{l}\text { Arrhenatherum } \\
\text { elatius }\end{array}$ \\
\hline
\end{tabular}

The calculated values of plant accumulation coefficients (the ratio of heavy metal concentration in plants to heavy metal concentration in the soil) for $\mathrm{Pb}$ and $\mathrm{Cd}$ varied (Tables 6 and 7). Those values for $\mathrm{Cd}$ were much higher than for $\mathrm{Pb}$. Much higher accumulation coefficient values for $\mathrm{Pb}$ and $\mathrm{Cd}$ were observed in underground parts of grass species. In the case of $\mathrm{Cd}$, the coefficient was the highest for $D$. glometara (2.456), whereas A. pratensis had the highest $\mathrm{Pb}$ coefficient (0.623). The average value for all species was the highest at $15 \mathrm{~m}$ from the road for $\mathrm{Cd}$ and at $1 \mathrm{~m}$ for $\mathrm{Pb}$. The findings of the present experiment indicated that in the case of $\mathrm{Pb}$ the average coefficient value for all grass species, and distances from the road were much lower than that provided by Malinowska and Jankowski (2016).

The pollution index $\left(P_{i}\right)$ quite is often used to assess soil contamination in areas close to expressways (Christoforidis 
Table 6 Accumulation coefficient for $\mathrm{Pb}$ and $\mathrm{Cd}$ in aboveground parts of selected grass species

\begin{tabular}{|c|c|c|c|c|c|c|c|}
\hline \multirow[t]{2}{*}{$\begin{array}{l}\text { Distance from the } \\
\text { road }(m)\end{array}$} & \multirow[t]{2}{*}{ Grass species } & \multicolumn{2}{|c|}{$\begin{array}{l}\text { Accumulation coef- } \\
\text { ficient }\end{array}$} & \multirow[t]{2}{*}{$\begin{array}{l}\text { Distance from the } \\
\operatorname{road}(\mathrm{m})\end{array}$} & \multirow[t]{2}{*}{ Grass species } & \multicolumn{2}{|c|}{$\begin{array}{l}\text { Accumulation coef- } \\
\text { ficient }\end{array}$} \\
\hline & & $\mathrm{Pb}$ & $\mathrm{Cd}$ & & & $\mathrm{Pb}$ & $\mathrm{Cd}$ \\
\hline \multirow[t]{3}{*}{1} & D. glomerata & 0.405 & 1.250 & 1 & D. glomerata & 0.683 & 2.587 \\
\hline & A. elatius & 0.282 & 0.825 & & A. elatius & 0.486 & 2.010 \\
\hline & A. pratensis & 0.393 & 0.503 & & A. pratensis & 0.630 & 2.254 \\
\hline \multirow[t]{3}{*}{5} & D. glomerata & 0.350 & 1.610 & 5 & D. glomerata & 0.500 & 2.369 \\
\hline & A. elatius & 0.288 & 0.613 & & A. elatius & 0.453 & 1.282 \\
\hline & A. pratensis & 0.258 & 0.562 & & A. pratensis & 0.435 & 1.550 \\
\hline \multirow[t]{3}{*}{10} & D. glomerata & 0.279 & 1.080 & 10 & D. glomerata & 0.470 & 2.281 \\
\hline & A. elatius & 0.291 & 1.570 & & A. elatius & 0.500 & 2.629 \\
\hline & A. pratensis & 0.424 & 0.686 & & A. pratensis & 0.649 & 2.252 \\
\hline \multirow[t]{3}{*}{15} & D. glomerata & 0.233 & 0.928 & 15 & D. glomerata & 0.435 & 2.586 \\
\hline & A. elatius & 0.104 & 0.454 & & A. elatius & 0.327 & 1.921 \\
\hline & A. pratensis & 0.449 & 0.914 & & A. pratensis & 0.687 & 3.079 \\
\hline \multicolumn{4}{|c|}{ Means for each distances } & \multicolumn{4}{|c|}{ Means for each distance } \\
\hline \multicolumn{2}{|l|}{1} & 0.360 & 0.859 & 1 & & 0.630 & 2.284 \\
\hline \multicolumn{2}{|l|}{5} & 0.297 & 0.928 & 5 & & 0.463 & 1.734 \\
\hline \multicolumn{2}{|l|}{10} & 0.331 & 1.11 & 10 & & 0.540 & 2.387 \\
\hline \multicolumn{2}{|l|}{15} & 0.262 & 0.765 & 15 & & 0.483 & 2.529 \\
\hline \multicolumn{4}{|c|}{ Means for each species } & \multicolumn{4}{|c|}{ Means for each species } \\
\hline \multicolumn{2}{|l|}{ D. glomerata } & 0.317 & 1.217 & D. glomerata & & 0.522 & 2.456 \\
\hline \multicolumn{2}{|l|}{ A. elatius } & 0.241 & 0.866 & A. elatius & & 0.442 & 1.961 \\
\hline \multicolumn{2}{|l|}{ A. pratensis } & 0.381 & 0.666 & A. pratensis & & 0.623 & 2.284 \\
\hline \multicolumn{4}{|l|}{ Means for element } & \multicolumn{4}{|l|}{ Means for element } \\
\hline & & 0.313 & 0.916 & & & 0.529 & 2.234 \\
\hline
\end{tabular}

and Stamatis 2009). The value of the index for $\mathrm{Cd}$ and $\mathrm{Pb}$ was above 1 in all measuring points, which meant mediumlevel pollution (Fig. 5). In the soil, the largest value of the pollution index $\left(P_{i}\right)$ for both metals was $5 \mathrm{~m}$ from the road.

Simple correlation coefficient values showed no significant interaction between $\mathrm{Pb}$ content in the plants and in the soil (Table 8). However, there was a significant positive correlation between $\mathrm{Cd}$ content in the soil and in the aboveground and underground parts of D. glomerata.

\section{Discussion}

This study presents the results of $\mathrm{Pb}$ and $\mathrm{Cd}$ content in the soil and grasses sampled at different distances from the expressway. In the soil, the average content of $\mathrm{Pb}$ and $\mathrm{Cd}$ was 10.37 and $0.221 \mathrm{mg} \mathrm{kg}^{-1}$, respectively. According to Martin et al. (2017) and Kabata-Pendias and Pendias (1999), such amounts were not high. The natural concentration of $\mathrm{Cd}$ in soils of the world ranges from 0.20 to $1.05 \mathrm{mg} \mathrm{kg}^{-1}$, usually not exceeding $0.5 \mathrm{mg} \cdot \mathrm{kg}^{-1} \mathrm{Cd}$ (Alloway 2013), whereas in
Table 7 Accumulation coefficient for $\mathrm{Pb}$ and $\mathrm{Cd}$ in underground parts

Poland it ranges from 0.03 to $0.22 \mathrm{mg} \mathrm{kg}^{-1} \mathrm{Cd}$ (KabataPendias 2004).

In the present study in the aboveground parts of grasses, the greatest amount of $\mathrm{Pb}\left(3.843 \mathrm{mg} \mathrm{kg}^{-1} \mathrm{DM}\right)$ was absorbed by Aloperucus pratensis and the smallest (3.246 $\left.\mathrm{mg} \mathrm{kg}^{-1} \mathrm{DM}\right)$ by Dactylis glomerata. Other studies (Viard et al. 2004) have found that $\mathrm{Pb}$ concentration in grass species (Festuca arundinacea, Phalaris species, $D$. glomerata L.) growing close to main roads ranged from 1.0 to $2.0 \mathrm{mg} \mathrm{kg}{ }^{-1} \mathrm{DM}$, whereas in samples collected 5 and $20 \mathrm{~m}$ away from the roadway, it was in the range of 0.8-2.2 and 0.5-0.7 $\mathrm{mg} \mathrm{kg}^{-1} \mathrm{DM}$, respectively. Some studies (Filipek-Mazur et al. 2007) performed in different parts of Poland have found that the average concentration of $\mathrm{Pb}$ in grass species was $2.5 \mathrm{mg} \mathrm{kg}^{-1} \mathrm{DM}$, ranging from 0.6 to $15 \mathrm{mg} \mathrm{kg}^{-1} \mathrm{DM}$. In other countries the average $\mathrm{Pb}$ concentration in grass species ranged from 0.4 (Finland) to $4.6 \mathrm{mg} \mathrm{kg}^{-1} \mathrm{DM}$ (Kazakhstan); as said above, in Poland the highest $\mathrm{Pb}$ concentration amounted to $15 \mathrm{mg} \mathrm{kg}^{-1} \mathrm{DM}$ (Filipek-Mazur et al. 2007). In the present study, Cd content in aboveground parts of grass ranged from $0.069 \mathrm{mg} \mathrm{kg}^{-1} \mathrm{DM}$ in A. elatius sampled at a distance of $15 \mathrm{~m}$ from the road to of selected grass species 
Fig. 5 Soil pollution indices for $\mathrm{Pb}$ and $\mathrm{Cd}$ in the vicinity of the E30 expressway

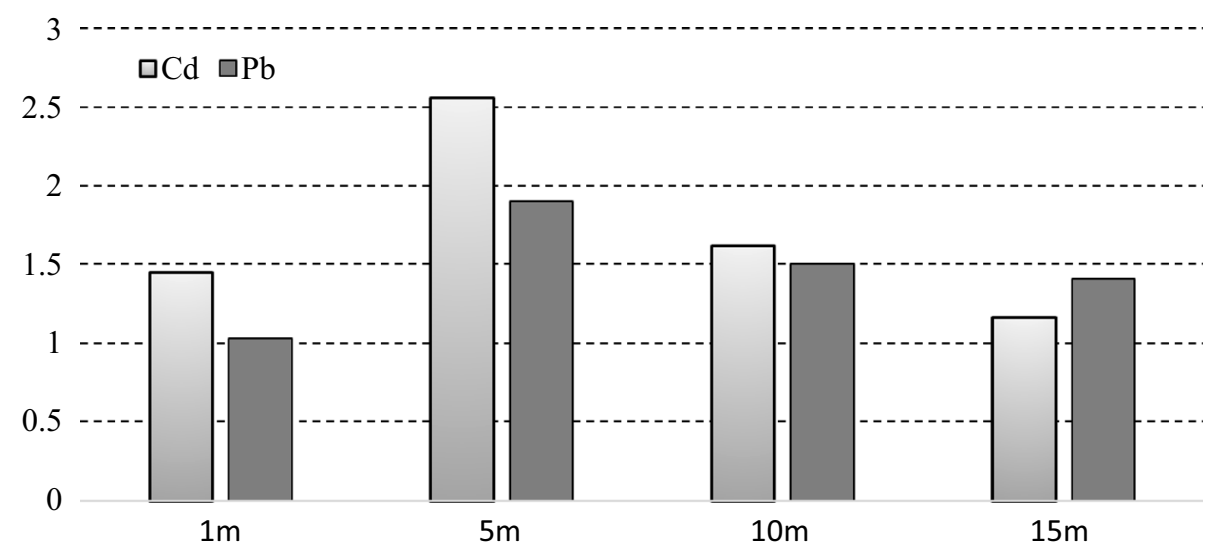

Table 8 Simple correlation coefficient between the overall content of $\mathrm{Pb}$ and $\mathrm{Cd}$ in the soil and in the above-ground and underground parts of selected grass species

\begin{tabular}{lll}
\hline Species & $\mathrm{Pb}$ & $\mathrm{Cd}$ \\
\hline Aboveground parts & & \\
$\quad$ Dactylis glomerate & 0.735 & $0.990^{*}$ \\
Arrhenatherum elatius & 0.676 & 0.371 \\
$\quad$ Alopecurus pratensis & 0.303 & 0.760 \\
Underground parts & & \\
Dactylis glomerate & 0.735 & $0.990^{*}$ \\
Arrhenatherum elatius & 0.822 & 0.371 \\
Alopecurus pratensis & 0.111 & 0.770 \\
\hline
\end{tabular}

$p \leq 0.05$

*Indicates significant difference

$0.537 \mathrm{mg} \mathrm{kg}^{-1} \mathrm{DM}$ in D. glomerata collected $5 \mathrm{~m}$ from the road. In some studies (Viard et al. 2004), Cd concentration in green parts of grass collected 5 and $20 \mathrm{~m}$ from the road was similar and ranged from 0.03 to $0.07 \mathrm{mg} \mathrm{kg}^{-1} \mathrm{DM}$. In other countries, $\mathrm{Cd}$ concentration in grass ranged from 1.0 to $1.6 \mathrm{mg} \mathrm{kg}^{-1} \mathrm{DM}$ (Belgium) and from 0.3 to $2.9 \mathrm{mg} \mathrm{kg}^{-1} \mathrm{DM}$ (Hungary). In Poland, the concentration of this chemical element varied between different species of grass in the range from 0.1 to $2.6 \mathrm{mg} \mathrm{kg}^{-1} \mathrm{DM}$, whereas for D. glomerata $\mathrm{L}$., these values ranged from 0.05 to $0.80 \mathrm{mg} \mathrm{kg}^{-1} \mathrm{DM}$ (Jankowski et al. 2015). According to Kabata-Pendias (2004), the maximum limits of the content of different heavy metals in forage are as follows: $<100 \mathrm{mg} \mathrm{Zn}<30 \mathrm{mg} \mathrm{Cu}$ $<20 \mathrm{mg} \mathrm{Cr}<50 \mathrm{mg} \mathrm{Ni}<10 \mathrm{mg} \mathrm{Pb}<0.5 \mathrm{mg} \mathrm{Cd} \mathrm{kg}^{-1} \mathrm{DM}$. In the present study, the content of $\mathrm{Pb}$ and $\mathrm{Cd}$ in the biomass of the grass species was within the above limits.

The ratio value for $\mathrm{Pb}$ and $\mathrm{Cd}$ showed different responses of each grass species to the release of heavy metals by traffic. The lowest value of $\mathrm{Cd}$ was reported in A. pratensis and the highest in D. glomerata. Underground parts of the grass species accumulated greater amounts of $\mathrm{Pb}$ and $\mathrm{Cd}$ than aboveground parts, which was indicated by accumulation coefficient values of $0.529 / 0.313$ and 2.234/0.916, respectively. In another study (Dai et al. 2004), three species of grass were exposed to extremely high levels of $\mathrm{Pb}$ and $\mathrm{Cd}$, with the ratio showing slightly different values from those of the present experiment. In the case of $\mathrm{Pb}$, it ranged from 0.01 to 0.02 and for $\mathrm{Cd}$ it was from 0.12 to 0.50 . The calculated values of accumulation coefficient for $\mathrm{Cd}$ were much higher than for $\mathrm{Pb}$. Additionally, Kloke et al. (1984) reported that of all heavy metals $\mathrm{Cd}$ had the greatest accumulation coefficient (1-10) and $\mathrm{Pb}$ the smallest (0.01-0.1). According to Kloke et al. (1984) and Kabata-Pendias and Pendias (1999), a coefficient value higher than 1 is a proof of intense accumulation of a metal by plants. Only in the case of the aboveground parts of $D$. glomerata was the coefficient higher than 1 (1.217). The present study indicates that considerable amounts of heavy metals that were released by vehicles on the expressway contaminated the soil.

\section{Conclusions}

Grass species tested in the experiment, namely D. glomerata L., A. pratensis L., and A. elatius L., had varied abilities to accumulate heavy metals. The largest amounts of $\mathrm{Pb}$ were absorbed by A. pratensis $\mathrm{L}$. $\left(3.843 \mathrm{mg} \mathrm{kg}^{-1}\right.$ $\mathrm{DM})$ and the lowest by A. elatius L. (2.523 $\left.\mathrm{mg} \mathrm{kg}^{-1} \mathrm{DM}\right)$. Of the above-mentioned plants, the highest amount of $\mathrm{Cd}$ $\left(0.286 \mathrm{mg} \mathrm{kg}^{-1} \mathrm{DM}\right)$ was accumulated by $D$. glomerata $\mathrm{L}$.

Underground parts of the grass species accumulated greater amounts of $\mathrm{Pb}$ and $\mathrm{Cd}$ than aboveground parts, which was indicated by the accumulation coefficient values of 0.633 and 0.436 , respectively. It indicates that considerable amounts of heavy metals released by vehicles on the expressway contaminated the soil.

The distance from the road clearly affected the content of heavy metals in the grass species. The highest amount of $\mathrm{Pb}$ and $\mathrm{Cd}$ was found in the grass growing at a distance of 
$5 \mathrm{~m}$ from the edge of the roadway, and this applies both to underground and aboveground parts. The results point to a need to monitor plant contamination by chemical elements released from road traffic, with a view to possible restrictions on the use of such plants as animal feed or medicine.

Funding The research was performed under the research theme No.213/04/S and financed from the science grant granted by the Ministry of Science and Higher Education.

\section{Compliance with ethical standards}

Conflict of interest The authors declare that the research was conducted in the absence of any commercial or financial relationships that could be construed as a potential conflict of interest.

Open Access This article is distributed under the terms of the Creative Commons Attribution 4.0 International License (http://creativeco mmons.org/licenses/by/4.0/), which permits unrestricted use, distribution, and reproduction in any medium, provided you give appropriate credit to the original author(s) and the source, provide a link to the Creative Commons license, and indicate if changes were made.

\section{References}

Adachia K, Tainosho Y (2004) Characterization of heavy metal particles embedded in tire dust. Environ Int 30:1009-1017

Alloway BJ (2013) Heavy metals in soils: trace metals and metalloids in soils and their bioavailability, 3rd edn. Springer, London

Chakrabortty S, Paratkar GT (2006) Biomonitoring of trace element air pollution using mosses. Aerosol Air Qual Res 6(3):247-258

Christoforidis A, Stamatis N (2009) Heavy metal contamination in street dust and roadside soil along the major national road in Kavala's region, Greece. Geoderma 151:257-263

Cicek A, Malkoc S, Koparal AS (2012) An investigation on the usability of grass in short term detection of traffic-related pollution. Arab J Sci Eng 37:1239-1245

Czarnowska K (1996) Total content of heavy metals in parent rocks as reference background levels of soils. Soil Sci Annu 47:43-50

Dai J, Becquer T, Rouiller JH, Reverast G, Bernhard-Reversat F, Lavelle P (2004) Influence of heavy metals on $\mathrm{C}$ and $\mathrm{N}$ mineralisation and microbial biomass in $\mathrm{Zn}-, \mathrm{Pb}-, \mathrm{Cu}-$ and $\mathrm{Cd}$-contaminated soils. Appl Soil Ecol 25:99-109

De Nicola F, Maisto G, Alfami A (2003) Assessment of nutritional status and trace element contamination of Holm oak woodlands through analyses of leaves and surrounding soils. Sci Total Environ 311:191-203

Deska J, Bombik A, Marciniuk-Kluska A, Rymuza K (2011) Trends in lead and cadmium contents in soils adjacent to European track E30. Pol J Environ Stud 2:317-325

European Environment Agency (2011) European Union emission inventory report 1990-2009 under the UNECE convention on long-range transboundary air pollution. EEA Technical Report 9:3

Filipek-Mazur B, Gondek K, Mazur K (2007) The impact of traffic pollution along the national road no 4 Bochnia-Sędziszów Małopolski) on the content of trace elements in soil and in meadow sward. Zesz Probl Post Nauk Rol 520:27-31

Garcia R, Milan E (1998) Assessment of $\mathrm{Cd}, \mathrm{Pb}$ and $\mathrm{Zn}$ in roadside soils and grasses from Gipuzkoa (Spain). Chemosphere 37(8):1615-1625
Gardea-Torresdey JI, Peralta-Videa JR, De la Rosa G, Parsons JG (2005) Phytoremediation of heavy metals and study of the metal coordination by X-ray absorption spectroscopy. Coord Chem Rev 249(17-18):1797-1810

General Directorate for National Road and Motorways (2015) The average daily traffic in Poland 2015. www.gddkia.gov.pl

Jankowski K, Jankowska J, Ciepiela GA, Wiśniewska-Kadżajan B, Kolczarek R, Deska J (2014) Lead and cadmium content in some grasses along expressway areas. J Elem 1:119-128. https://doi. org/10.5601/jelem.2014.19.1.591

Jankowski K, Ciepiela AG, Jankowska J, Szulc W, Kolczarek R, Sosnowski J, Wiśniewska-Kadżajan B, Malinowska E, Radzka E, Czeluścinski W, Deska J (2015) Content of lead and cadmium in aboveground plant organs of grasses growing on the areas adjacent to a route of big traffic. Environ Sci Pollut Res 22(2):978987. https://doi.org/10.1007/s11356-014-3634-9

Kabata-Pendias A (2004) Soil-plant transfer of trace elements-an environmental issue. Geoderma 122:143-149

Kabata-Pendias A, Pendias H (1999) Biogeochemistry of trace elements. PWN, Warszawa

Kloke A, Sauerbeck DR, Vetter H (1984) The contamination of plants and soils with heavy metals and the transport of metals in terrestrial food chains. In: Nriagu JO (ed) Changing metal cycles and human health. Springer, Berlin, pp 113-141

Lai HY, Chen ZS (2004) Effects of EDTA on solubility of cadmium, zinc, and lead and their uptake by rainbow pink and vetiver grass. Chemosphere 55:421-430

Location of the analysed samples [online]. Available at: http://www. openstreetmap.org/\#map=12/52.1036/22.1357. Accessed 11 Mar 2018

Malinowska E, Jankowski K (2016) Impact of agricultural chemicals on selected heavy metals accumulation in herbs plants. App Ecol Environ Res 4(3):479-487. https://doi.org/10.15666/ aeer/1403_479487

Malinowska E, Jankowski K, Wiśniewska-Kadżajan B, Jankowska J, Sosnowski J, Ciepiela GA, Szulc W, Kolczarek R (2015) Content of zinc in different grass species growing along a fast highway. Fresenius Environ Bull 24(11a):3759-3765

Martin AP, Turnbull RE, Rissmann CW, Rieger P (2017) Heavy metal and metalloid concentrations in soils under pasture of southern New Zealand. Geoderma Regional 11:18-27

Maslin P, Maier RM (2000) Rhamnolipid-enhanced mineralization of phenanthrene in organic-metal co-contaminated soils. Biorem J 4(4):295-308

McKenzie ER, Money JE, Gren PG, Young TM (2009) Metals associated with stormwater-relevant brake and tire samples. Sci Total Environ 407:5855-5860

McLaughlin MJ, Hamon RE, McLaren RG, Speir TW, Rogers SL (2000) Review: a bioavailability-based rationale for controlling metal and metalloid contamination of agricultural land in Australia and New Zealand. Soil Res 38(6):1037-1086

Mulligan C, Yong R, Gibbs B (2001) Remediation technologies for metal-contaminated soils and groundwater: an evaluation. Eng Geol 60(1):193-207

Naszradi T, Badacsonyi A, Nemeth N, Tuba Z, Batic F (2004) Zinc, lead and cadmium content in meadow plants and mosses along the motorway (Hungary). J Atmos Chem 49:593-603

Olajire AA, Ayodele ET (1997) Contamination of roadside soil and grass with heavy metals. Environ Int 23(1):91-101

Peralta-Videa JR, Lopez ML, Narayan M, Saupe G, Gardea-Torresdey J (2009) The biochemistry of environmental heavy metal uptake by plants; implications for the food chain. Int J Biochem Cell B 41(8):1665-1677

Pulles T, van der Gon HD, Appelman W, Verheul M (2012) Emission factors for heavy metals from diesel and petrol used in European vehicles. Atmos Environ 61:641-651 
Regulations of the Minister for Agriculture and Rural Development of 23 January 2007 on the permissible contents of undesirable substances in fodder, Daily Law Number 20. Position 119

Serbula SM, Miljkovic DD, Kovacevic RM, Ilic AA (2012) Assessment of airborne heavy metal pollution using plant parts and topsoil. Ecotoxicol Environ Saf 76:209-214

Stafilov T, Jordanovska V (1997) Determination of cadmium in some vegetables produced in the area near the lead and zinc smelting plant in Veles, Macedonia. Ecol Prot Environ 4:35-38

Tomasevic M, Rajsic S, Dord-evic D, Tasic M, Krstic J, Novakovic V (2004) Heavy metals accumulation in tree leaves from urban areas. Environ Chem Lett 2:151-154
Vachova P, Vach M, Najnarova E (2017) Using expansive grasses for monitoring heavy metal pollution in the vicinity of roads. Environ Poll 229:94-101

Viard B, Pihan F, Promeyrat S, Pihan JC (2004) Integrated assessment of heavy metal $(\mathrm{Pb}, \mathrm{Zn}, \mathrm{Cd})$ highway pollution: bioaccumulation in soil, Graminaceae and land snails. Chemosphere 55:1349-1359

Werkenthin M, Kluge Björn K, Wessolek G (2014) Metals in European roadside soils and soil solution: a review. Environ Poll 189:98-110

Wiśniewska-Kadżajan B, Jankowski K, Malinowska E, Kolczarek R, Sosnowski J, Jankowska J, Ciepiela GA, Szulc W (2015) Copper content in some grasses from the areas adjacent to the E30 highway in Poland. Fresenius Environ Bull 24(2):498-5904 